U.S. Department of the Interior

U.S. Geological Survey

Total Dissolved Gas and Water Temperature in the Lower Columbia River, Oregon and Washington, 2002: Quality-Assurance Data and Comparison to Water-Quality Standards

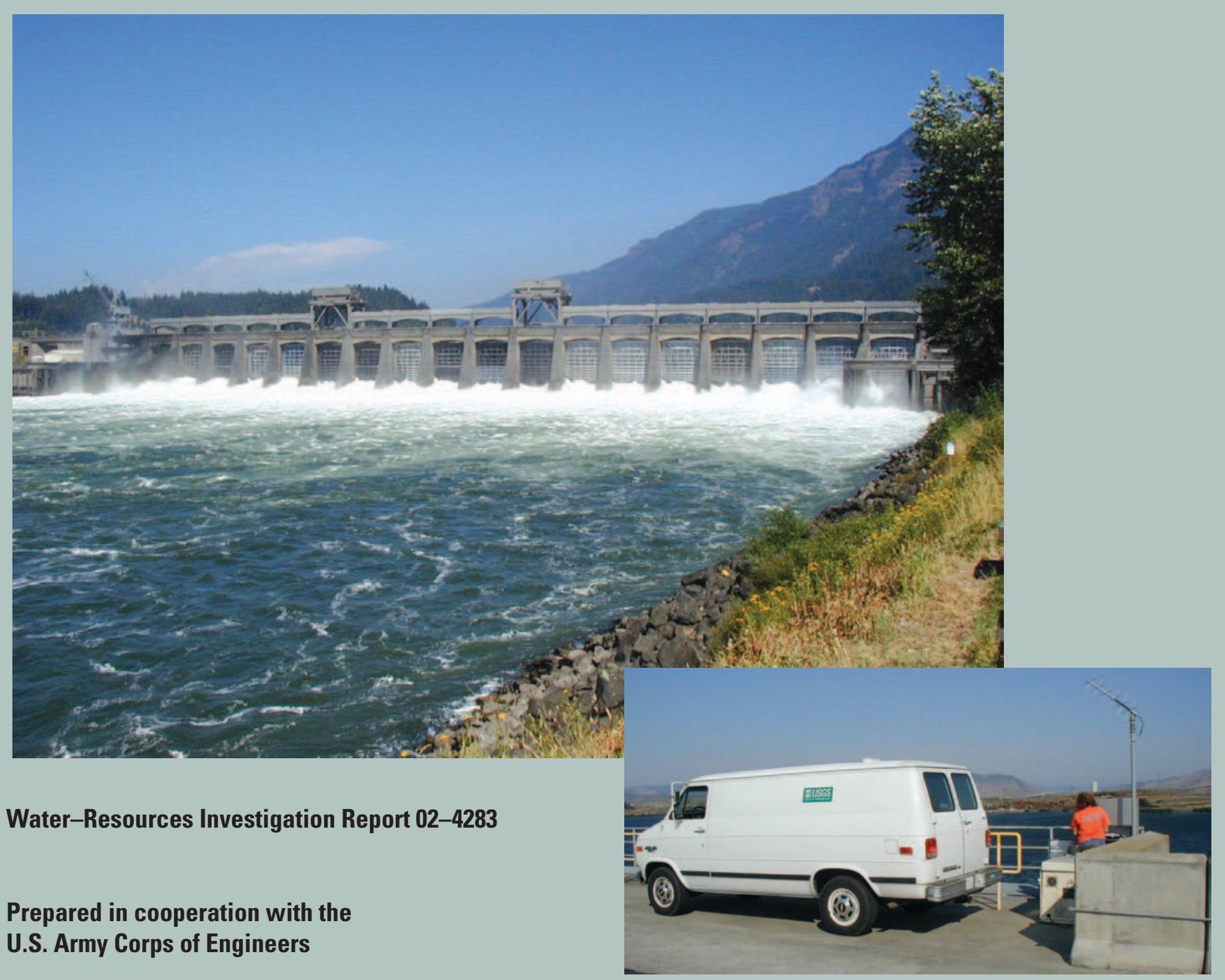




\section{Cover photographs:}

Upper left: Spill from Bonneville Dam, Columbia River, July 2002.

Lower right: Calibrating equipment on the Columbia River at The Dalles Dam forebay, July 2002.

(Photographs by Rebecca Treat, U.S. Geological Survey volunteer) 


\section{Total Dissolved Gas and Water Temperature in the Lower Columbia River, Oregon and Washington, 2002: Quality-Assurance Data and Comparison to Water-Quality Standards}

BY DWIGHT Q. TANNER, MATTHEW W. JOHNSTON, and HEATHER M. BRAGG

Water-Resources Investigations Report 02-4283

Prepared in cooperation with the

U.S. ARMY CORPS OF ENGINEERS

Portland Oregon: 2002 


\section{U. S. DEPARTMENT OF THE INTERIOR \\ GALE A. NORTON, Secretary}

\section{U.S. GEOLOGICAL SURVEY}

CHARLES G. GROAT, Director

The use of trade, product, or firm names in this publication

is for descriptive purposes only and does not imply

endorsement by the U.S. Government.

For additional information:

Copies of this report may be purchased from:

District Chief

U.S. Geological Survey

10615 S.E. Cherry Blossom Dr.

USGS Information Services

Portland, 0R 97216-3159

Box 25286

Denver, CO 80225-0286

E-mail: info-or@usgs.gov

Telephone: 1-888-ASK-USGS

Internet: http://oregon.usgs.gov

Suggested citation:

Tanner, D.0., Johnston, M.W., and Bragg, H.M., 2002, Total dissolved gas and water temperature in the lower Columbia River, Oregon and Washington, 2002-Quality-assurance data and comparison to water-quality standards: U.S. Geological Survey Water-Resources Investigations Report 02-4283, 12 p. 


\section{CONTENTS}

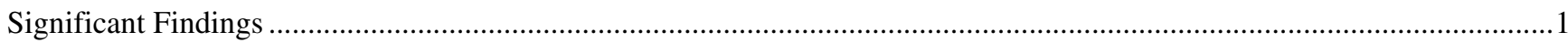

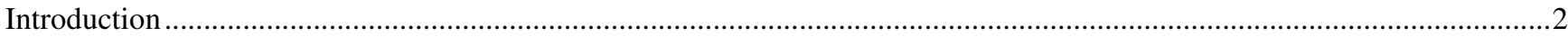

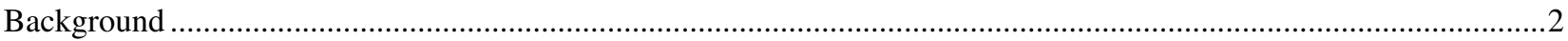

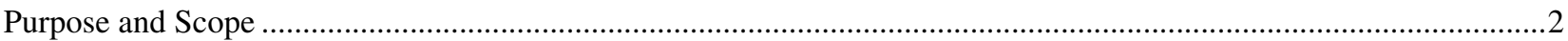

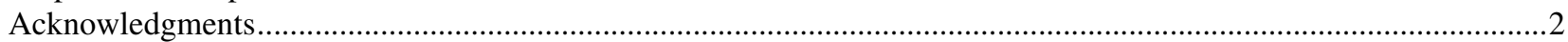

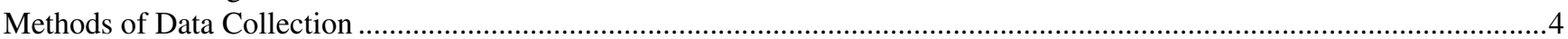

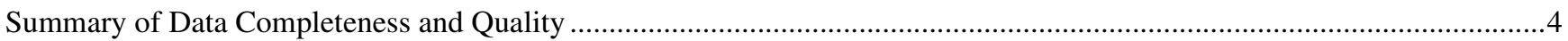

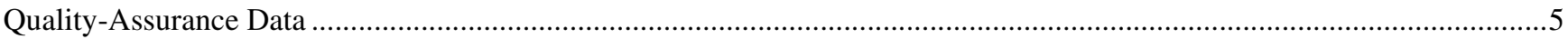

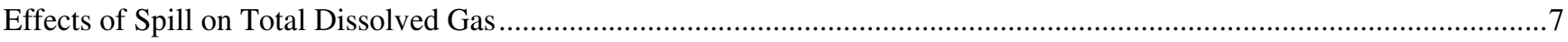

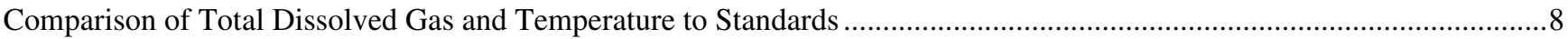

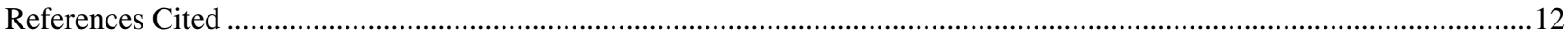

\section{FIGURES}

1 Map showing location of total-dissolved-gas fixed stations, lower Columbia River, Oregon and Washington, water year 2002

2.-13. Graphs showing:

2. Accuracy of total-dissolved-gas sensors when compared to a certified pressure gage after 2 to 3 weeks

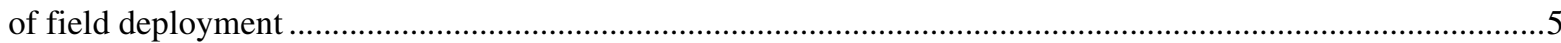

3. Difference between the secondary standard and the field barometers ...........................................................6

4. Difference between the secondary standard and the field temperature instruments .........................................6

5. Difference between the secondary standard and the field total-dissolved-gas instruments .............................6

6. Total dissolved gas downstream of John Day Dam and spill from John Day Dam .......................................

7. Total dissolved gas downstream of The Dalles Dam and spill from The Dalles Dam ........................................ 8

8. Total dissolved gas downstream of Bonneville Dam at Warrendale and spill from Bonneville Dam ..................9

9. Total-dissolved-gas distributions and exceedances of Oregon Water-Quality variances,

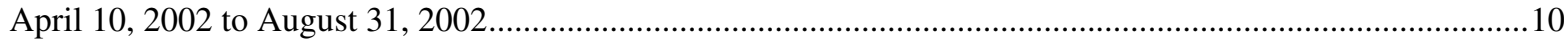

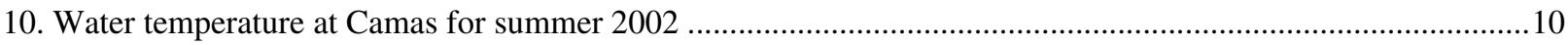

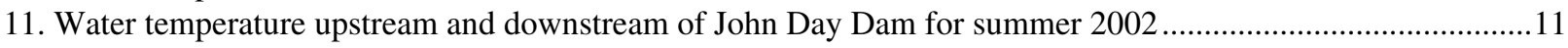

12. Water temperature upstream and downstream of The Dalles Dam for summer 2002 ....................................11

13. Water temperature upstream and downstream of Bonneville Dam for summer 2002 ...................................12

\section{TABLES}

1. Total-dissolved-gas fixed stations, lower Columbia River, Oregon and Washington, water year 2002 …......................

2. Total-dissolved-gas data completeness and quality, water year 2002 .....................................................................4

3. Exceedances of State of Oregon Water-Quality variances for total dissolved gas, lower Columbia River, Oregon and Washington, water year 2002

\section{CONVERSION FACTORS}

\begin{tabular}{rll}
\hline Multiply & By & To obtain \\
\hline inch (in) & 2.54 & centimeter $(\mathrm{cm})$ \\
mile $(\mathrm{mi})$ & 1.609 & kilometer $(\mathrm{km})$ \\
square ${\mathrm{mile}\left(\mathrm{mi}^{2}\right)}_{\text {cubic feet per second }\left(\mathrm{ft}^{3} / \mathrm{s}\right)}^{2.59}$ & 0.028317 & square kilometer $\left(\mathrm{km}^{2}\right)$ \\
cubic meters per second $\left(\mathrm{m}^{3} / \mathrm{s}\right)$ \\
\hline
\end{tabular}

Temperature in degrees Celsius $\left({ }^{\circ} \mathrm{C}\right)$ may be converted to Fahrenheit $\left({ }^{\circ} \mathrm{F}\right)$ as follows:

$$
{ }^{\circ} \mathrm{F}=\left(1.8 \times{ }^{\circ} \mathrm{C}\right)+32
$$


This page intentionally blank 


\title{
Total Dissolved Gas and Water Temperature in the Lower Columbia River, Oregon and Washington, 2002: Quality-Assurance Data and Comparison to Water-Quality Standards
}

\author{
By Dwight 0. Tanner, Matthew W. Johnston, and Heather M. Bragg
}

\section{SIGNIFICANT FINDINGS}

The U.S. Geological Survey (USGS), in cooperation with the U.S. Army Corps of Engineers, collected total-dissolved-gas and water-temperature data at eight sites near dams on the lower Columbia River in 2002. When water is released through the spillways of dams, air is entrained in the water, increasing the concentration of total dissolved gas to levels that can have adverse effects on freshwater aquatic life. Significant findings include:

- For the eight monitoring sites in water year 2002, an average of $99.6 \%$ of the total-dissolvedgas data were received in real time by the USGS satellite downlink and were within $1 \%$ saturation of the expected value, based on calibration data and ambient river conditions at adjacent sites.

- Most field checks of total-dissolved-gas sensors with a secondary standard were within $1 \%$ saturation. Field checks of barometric pressure and water temperature were usually within 1 millimeter of mercury and 0.05 degrees Celsius, respectively.

- In June and July 2002, spills exceeded 140,000 cubic feet per second at the John Day,
The Dalles, and Bonneville Dams. These spills resulted in levels of total dissolved gas that exceeded $120 \%$ saturation downstream of the dams.

- The variance to the State of Oregon waterquality standard for total dissolved gas of $110 \%$ saturation was exceeded at seven of the eight monitoring sites. The sites at Camas and Bonneville are considered forebay sites and had the most days exceeding the variance of $115 \%$ saturation. The forebay exceedances may have been the result of the cumulative effects of significant spill throughout the lower Columbia River. Apparently, the levels of total dissolved gas did not dissipate rapidly enough downstream of the dams before reaching the next site.

- From mid-July to mid-September, water temperatures were usually above 20 degrees Celsius at each of the seven lower Columbia River sites in operation. According to the Oregon water-quality standard, when the temperature of the lower Columbia River exceeds 20 degrees Celsius, no measurable temperature increase resulting from anthropogenic activities is allowed. 


\section{INTRODUCTION}

The U.S. Army Corps of Engineers (USACE) operates several dams in the Columbia River Basin, which encompasses 259,000 square miles of the Pacific Northwest. These dams are multipurpose facilities that fill regional needs for flood control, navigation, irrigation, recreation, hydropower production, fish and wildlife habitat, water-quality maintenance, and municipal and industrial water supply. When water is released through the spillways of these dams (instead of being routed through the turbines to generate electricity), air is entrained in the water, increasing the concentration of total dissolved gas (TDG) downstream from the spillways. Consequently, TDG may exceed Oregon and Washington water-quality standards for the protection of freshwater aquatic life. Concentrations above $110 \%$ saturation have been shown to cause gas-bubble trauma in fish and adversely affect other aquatic organisms (U.S. Environmental Protection Agency, 1986). The USACE regulates spill and streamflow to minimize the production of excess TDG downstream from its dams, and to provide for fish passage other than through the turbines. The USACE oversees the collection of near real-time TDG and water-temperature data (data available within about 4 hours of current time) upstream and downstream from the dams in a network of fixedstation monitors.

\section{Background}

Real-time TDG and water-temperature data are vital to the USACE for dam operation and for monitoring compliance with environmental regulations. The data are used by water managers to maintain water-quality conditions that facilitate fish passage and survival in the lower Columbia River. The U.S. Geological Survey (USGS), in cooperation with the Portland District of the USACE, has collected TDG and related data in the lower Columbia River every year beginning in 1996. Current and historical TDG and water-temperature data can be found on the USGS website at http://oregon.usgs.gov/projs_dir/ pn307.tdg/. Reports that were published in 1996 and 2001 contained TDG data, quality-assurance data, and descriptions of the methods of data collection for water years 1996, 2000, and 2001 (Tanner and others, 1996; Tanner and Johnston, 2001; and Tanner and Bragg, 2001, respectively).
To provide suitable data for managing and modeling TDG in the lower Columbia River, real-time hourly data for 2002 were reviewed relative to measurements made during instrument calibration. Some TDG data were deleted because they were not of suitable quality. The reviewed hourly data were stored in a USGS data base (Automated Data Processing System-ADAPS); and in a USACE data base (Columbia River Operation Hydromet Management System-CROHMS at http://www.nwd-wc.usace. army.mil/TMT/tdg_data/). The USACE data base also includes discharge and spill data.

\section{Purpose and Scope}

The purpose of TDG monitoring in the lower Columbia River is to provide the USACE with (1) real-time data for managing streamflow and spill at its project dams and (2) reviewed TDG data to evaluate conditions in relation to water-quality standards and to provide a data base for modeling the effect of various management scenarios of streamflow and spill on TDG levels.

This report describes the TDG data and related quality-assurance data for the monitoring program on the lower Columbia River from the forebay of the John Day Dam (river mile [RM] 215.6) to Camas, Washington (RM 121.7). Data for water year (WY) 2002 (October 1, 2001, to September 30, 2002) included hourly measurements of TDG pressure, barometric pressure, water temperature, and probe depth at eight fixed stations on the lower Columbia River (fig. 1, table 1). Five sites were operated from March to September, two were operated year-round, and one site, near Skamania (site 6), was operated only during March 2002, a critical time for fisheries below Bonneville Dam.

\section{Acknowledgments}

The authors acknowledge the aid and funding support of the U.S. Army Corps of Engineers. Our special thanks goes to James L. Britton (USACE) for technical and logistical support of the project. The authors also acknowledge Amy Brooks (USGS) for assistance in data collection and for preparing summaries and analyses of data. Rebecca Treat and Ian Wigger, USGS volunteers, assisted with data collection in the field. 


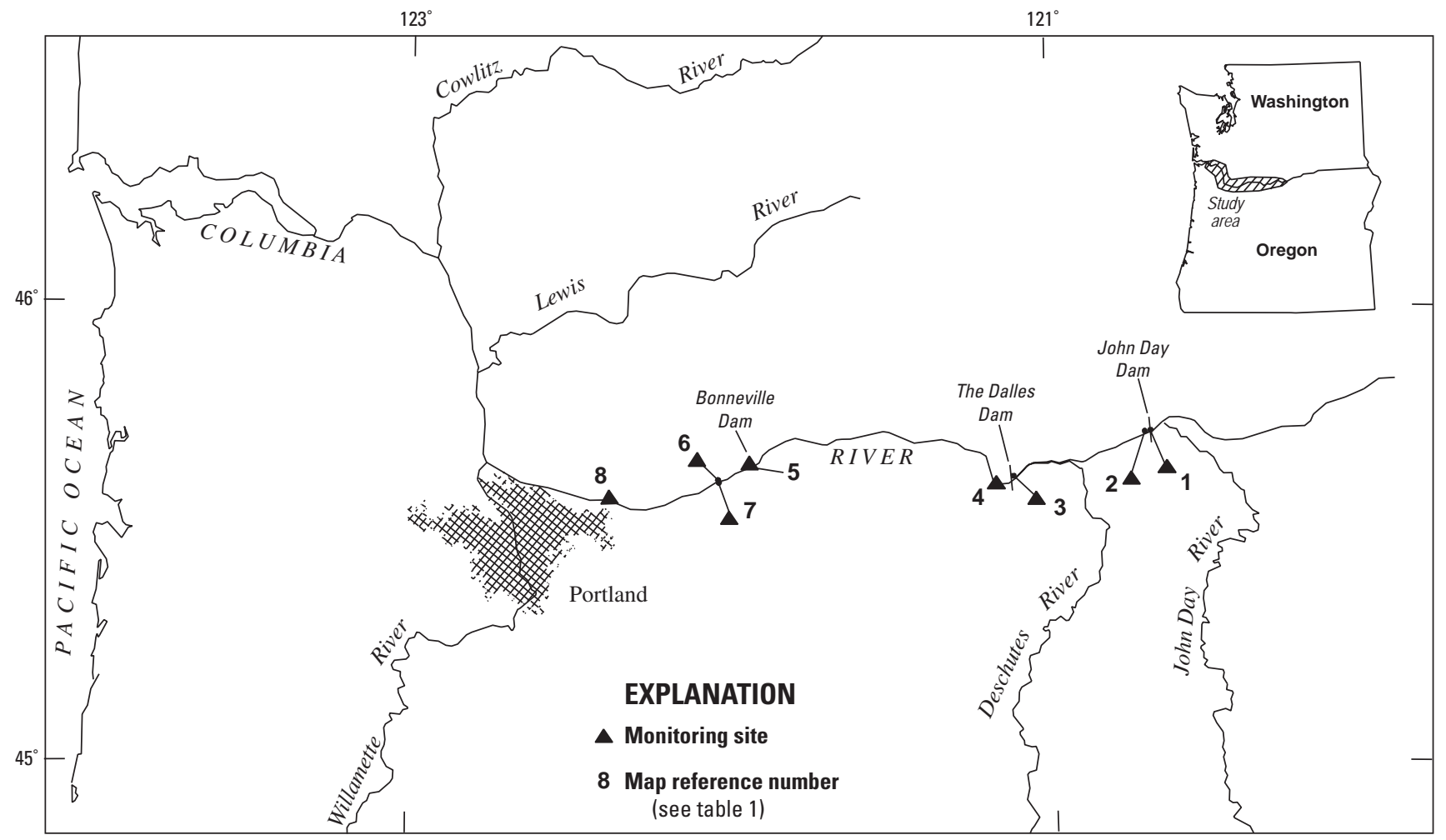

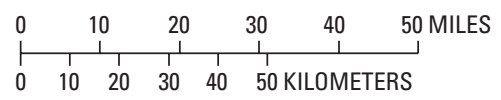

Figure 1. Location of total-dissolved-gas fixed stations, lower Columbia River, Oregon and Washington, water year 2002.

Table 1. Total-dissolved-gas fixed stations, lower Columbia River, Oregon and Washington, water year 2002

[Map reference number refers to figure 1; USACE, U.S. Army Corps of Engineers; Columbia River mile locations were determined from U.S. Geological Survey (USGS) 7.5-minute topographic maps; stations are referenced by their abbreviated name or USACE site identifier in this report; ${ }^{\circ}$, degree; ', minute; ", second]

\begin{tabular}{|c|c|c|c|c|c|c|c|}
\hline $\begin{array}{c}\text { Map } \\
\text { reference } \\
\text { number }\end{array}$ & $\begin{array}{c}\text { USACE } \\
\text { site } \\
\text { identifier }\end{array}$ & $\begin{array}{c}\text { Columbia } \\
\text { River } \\
\text { mile }\end{array}$ & $\begin{array}{l}\text { USGS } \\
\text { station number }\end{array}$ & $\begin{array}{l}\text { USGS station name } \\
\text { (abbreviated station name) }\end{array}$ & Latitude & Longitude & $\begin{array}{c}\text { Period } \\
\text { of } \\
\text { record }\end{array}$ \\
\hline 1 & JDA & 215.6 & 454257120413000 & $\begin{array}{l}\text { Columbia River at John Day Dam forebay, } \\
\text { Washington (John Day forebay) }\end{array}$ & $45^{\circ} 42^{\prime} 57^{\prime \prime}$ & $120^{\circ} 41^{\prime} 30^{\prime \prime}$ & $\begin{array}{l}03 / 27 / 02- \\
09 / 27 / 02\end{array}$ \\
\hline 2 & JHAW & 214.7 & 454249120423500 & $\begin{array}{l}\text { Columbia River, right bank, near Cliffs, } \\
\text { Washington (John Day tailwater) }\end{array}$ & $45^{\circ} 42^{\prime} 49^{\prime \prime}$ & $120^{\circ} 42^{\prime} 35^{\prime \prime}$ & $\begin{array}{l}03 / 27 / 02- \\
09 / 27 / 02\end{array}$ \\
\hline 3 & TDA & 192.6 & 453712121071200 & $\begin{array}{l}\text { Columbia River at The Dalles Dam forebay, } \\
\text { Washington (The Dalles forebay) }\end{array}$ & 45³7’12”' & $121^{\circ} 07^{\prime} 12^{\prime \prime}$ & $\begin{array}{l}03 / 26 / 02- \\
09 / 30 / 02\end{array}$ \\
\hline 4 & TDDO & 188.9 & 14105700 & $\begin{array}{l}\text { Columbia River at The Dalles, } \\
\text { Oregon (The Dalles tailwater) }\end{array}$ & $45^{\circ} 36^{\prime} 27^{\prime \prime}$ & $121^{\circ} 10^{\prime} 20^{\prime \prime}$ & $\begin{array}{l}03 / 26 / 02- \\
09 / 30 / 02\end{array}$ \\
\hline 5 & BON & 146.1 & 453845121562000 & $\begin{array}{l}\text { Columbia River at Bonneville Dam forebay, } \\
\text { Washington (Bonneville forebay) }\end{array}$ & $45^{\circ} 38^{\prime} 45^{\prime \prime}$ & $121^{\circ} 56^{\prime} 20^{\prime \prime}$ & Year-round \\
\hline 6 & SKAW & 140.5 & 453651122022200 & $\begin{array}{l}\text { Columbia River, right bank, near Skamania, } \\
\text { Washington (Skamania) }\end{array}$ & $45^{\circ} 36^{\prime} 51^{\prime \prime}$ & $122^{\circ} 02^{\prime} 22^{\prime \prime}$ & $\begin{array}{l}02 / 28 / 02- \\
03 / 29 / 02\end{array}$ \\
\hline 7 & WRNO & 140.4 & 453630122021400 & $\begin{array}{l}\text { Columbia River, left bank, near Dodson, } \\
\text { Oregon (Warrendale) }\end{array}$ & $45^{\circ} 36^{\prime} 30^{\prime \prime}$ & $122^{\circ} 02^{\prime} 14^{\prime \prime}$ & Year-round \\
\hline 8 & CWMW & 121.7 & 453439122223900 & $\begin{array}{l}\text { Columbia River, right bank, at Washougal, } \\
\text { Washington (Camas) }\end{array}$ & $45^{\circ} 34^{\prime} 39^{\prime \prime}$ & $122^{\circ} 22^{\prime} 39^{\prime \prime}$ & $\begin{array}{l}02 / 28 / 02- \\
09 / 30 / 02\end{array}$ \\
\hline
\end{tabular}




\section{METHODS OF DATA COLLECTION}

Methods of data collection for TDG, barometric pressure, and water temperature are described in detail in Tanner and Johnston, 2001. A summary of these methods follows. Instrumentation at each fixed station consisted of a Hydrolab water-quality probe, a Common Sensing, Inc. electronic barometer, a power supply, and a Sutron Model 8200 data-collection platform (DCP). The barometer, probe, and DCP were powered by a 12 -volt battery that was charged by a solar panel and/or a 120-volt alternating-current line. Measurements were made every hour, and every 4 hours the DCP transmitted the most recent logged data to the Geostationary Operational Environmental Satellite (GOES) system (Jones and others, 1991). The data were automatically decoded and transferred to the USACE data base CROHMS, and to the USGS ADAPS data base. At one site, John Day tailwater, two TDG sensors were installed on the same Hydrolab. This was done to ensure that data were reliably collected at this important site.

The fixed-station monitors were calibrated every 2 weeks from March to September 2002, and every 3 weeks for the remainder of the water year, at which time Warrendale and Bonneville forebay were the only sites in operation. The field calibration procedure is outlined below. A recently calibrated Hydrolab (which was used as a secondary standard) was deployed alongside of the field Hydrolab to obtain check measurements of TDG and water temperature prior to removing the field Hydrolab for calibration. Then the field Hydrolab was replaced with one that had been recently calibrated at the Oregon District Laboratory. Again, the secondary standard was used to check TDG and temperature in the river. The electronic barometer at the fixed station was calibrated using a portable barometer that had been recently calibrated at the National Weather Service office located in northeast Portland.

The Hydrolab that was brought in from the field after 2 to 3 weeks of deployment was then calibrated in the Oregon District Laboratory. The integrity of the TDG membrane was checked, and the TDG sensor was calibrated at $0,100,200$, and $300 \mathrm{~mm} \mathrm{Hg}$ (millimeters of mercury) above atmospheric pressure to cover the expected range of TDG pressure in the river $(100,113,126$, and $139 \%$ saturation, respectively).

During each field calibration, the minimum compensation depth was calculated to determine whether the Hydrolab was positioned at an appropriate depth to measure TDG. This depth, which was calculated according to Colt $(1984$, p. 104), is the depth above which degassing will occur, due to decreased hydrostatic pressure. To measure TDG accurately, the Hydrolabs were positioned during each calibration visit at a depth below the calculated minimum compensation depth, wherever possible.

\section{SUMMARY OF DATA COMPLETENESS AND QUALITY}

A summary of USGS TDG data completeness and quality for WY 2002 is shown in table 2. (The USACE satellite downlink operated independently, but the amount and quality of USACE data were similar). Data in table 2 were based on the total amount of hourly TDG data that could have been collected during the monitoring season. Any hour without TDG pressure data or barometric pressure data was counted as an hour of missing data for TDG in percent saturation, which is calculated as total dissolved gas pressure, in millimeters of mercury, divided by the barometric pressure, in millimeters of mercury, multiplied by 100. The fourth column in table 2 shows the percentage of data that was received in real time and passed quality-assurance checks. TDG data were considered to meet quality-assurance standards if they were within $1 \%$ saturation of the expected value, based on calibration data and daily checks of ambient river conditions at adjacent sites.

Table 2. Total-dissolved-gas data completeness and quality, water year 2002

[TDG, total dissolved gas]

\begin{tabular}{lccc}
\hline $\begin{array}{c}\text { Abbreviated } \\
\text { station } \\
\text { name }\end{array}$ & $\begin{array}{c}\text { Planned } \\
\text { monitoring, } \\
\text { in hours }\end{array}$ & $\begin{array}{c}\text { Number of } \\
\text { missing hourly } \\
\text { values }\end{array}$ & $\begin{array}{c}\text { Percentage } \\
\text { of real-time } \\
\text { TDG data passing } \\
\text { quality assurance }\end{array}$ \\
\hline John Day forebay & 4,417 & 9 & 99.8 \\
John Day tailwater & 4,414 & 5 & 99.9 \\
The Dalles forebay & 4,522 & 31 & 99.3 \\
The Dalles tailwater & 4,524 & 11 & 99.8 \\
Bonneville forebay & 8,760 & 101 & 98.8 \\
Skamania & 697 & 0 & 100 \\
Warrendale & 8,760 & 44 & 99.5 \\
Camas & 5,149 & 26 & 99.5 \\
\hline \hline Average & -- & -- & 99.6 \\
\hline
\end{tabular}


At each station, at least $98.8 \%$ of the data was received in real time by the USGS downlink and met quality-assurance standards, with an overall average of $99.6 \%$ (table 2). Missing hourly values were usually due to malfunction of the data-collection platform or mistakes in programming it. The lowest percentage for a station was $98.8 \%$ at Bonneville forebay. Most of this data loss occurred in March, due to transmission problems as a result of a faulty battery and cable.

\section{QUALITY-ASSURANCE DATA}

Data collection for TDG, barometric pressure and water temperature involved several qualityassurance procedures, including calibration of instruments in the field and in the laboratory, daily checks of the data, and data review and archive (Tanner and Johnston, 2001). The qualityassurance data for WY 2002 are presented in this section.

After field deployment for 2 to 3 weeks, the TDG sensors were calibrated in the laboratory. First, the unit was tested, with the membrane in place, for response to increased pressure and to supersaturation conditions. The membrane was then removed from the sensor and allowed to dry for at least 24 hours. Before replacing the membrane, the TDG sensor was examined independently. The calibration test procedure compared the reading of the TDG sensor to barometric pressure (100\% saturation). Using a certified digital pressure gage (primary standard), comparisons also were made at pressures of 100, 200 and $300 \mathrm{~mm} \mathrm{Hg}$ above barometric pressure (approximately 113\%, $126 \%$, and $139 \%$ saturation, respectively). The accuracy of the TDG sensors was calculated by computing the difference between the expected reading and the TDG sensor reading (expected minus actual) for each of the four test conditions. As shown in figure 2, most of the sensor readings fell within $0.2 \%$ saturation and all were well within $1 \%$.

After 2 to 3 weeks of field deployment, the differences in barometric pressure, water temperature and TDG between the fixed-station monitors and the recently calibrated secondary standard instruments were measured and recorded as part of the field inspection and calibration procedure. These differences (secondary standard minus field instrument) were used to compare and quantify the precision between the two independent instruments.

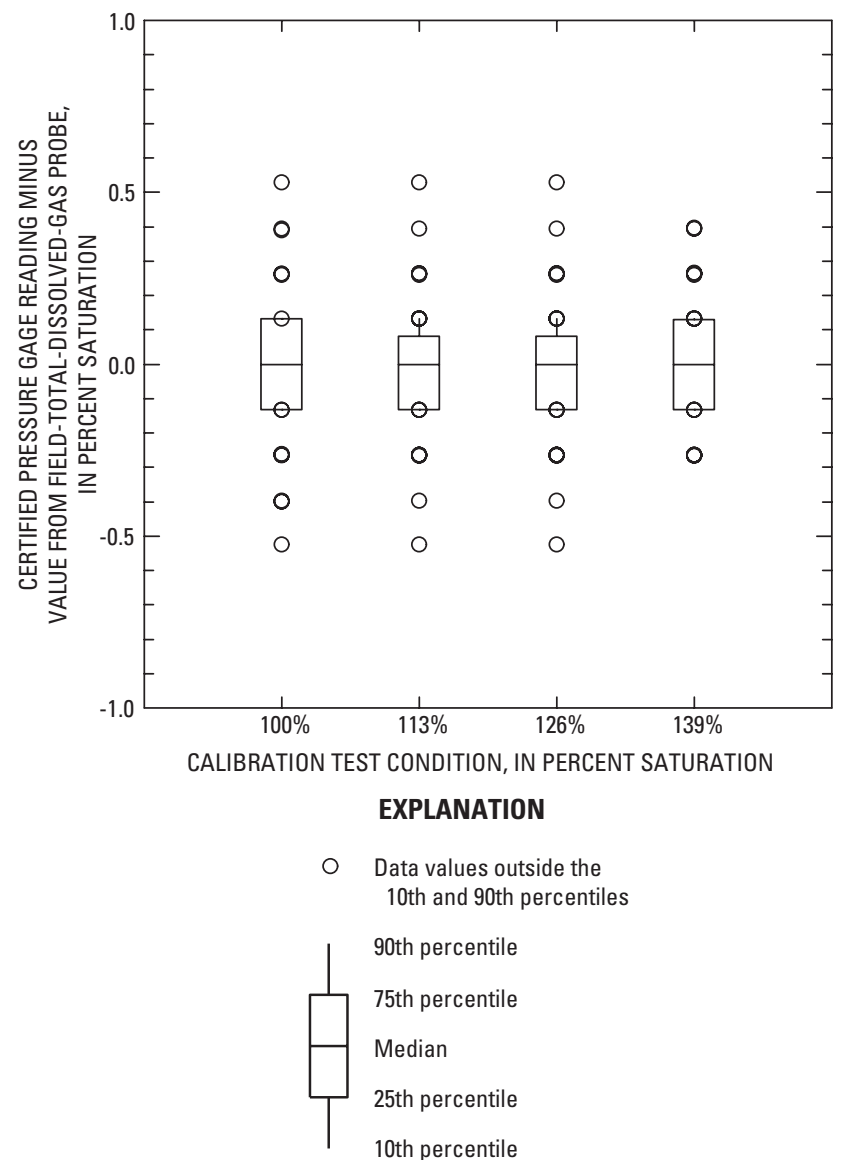

Figure 2. Accuracy of total-dissolved-gas sensors when compared to a certified pressure gage after 2 to 3 weeks of field deployment. (130 tests were conducted at each pressure.)

For water temperature and TDG, the measurements were made in-situ with the secondary standard (a recently calibrated Hydrolab) positioned alongside the field Hydrolab in the river. An aneroid barometer, calibrated every 3 to 4 weeks, served as the secondary standard for barometric pressure. Figures 3, 4, and 5 illustrate the distribution of quality-assurance data for each of the three parameters from seven field sites.

The comparisons of the aneroid barometer and the electronic field barometers are shown in figure 3. Most of the field values were within $1 \mathrm{~mm}$ of the standard values, and the median difference at each site was zero. The only difference greater than $3 \mathrm{~mm} \mathrm{Hg}$ was the initial calibration (adjustment of the DCP offset values) of the field barometer at the John Day tailwater site. The temperature sensor secondary standard and the field temperature sensor results are presented in figure 4. Most of the differences were within $0.05^{\circ} \mathrm{C}$ (degrees Celsius); however, the primary standard was certified only to plus or minus $0.1^{\circ} \mathrm{C}$. 


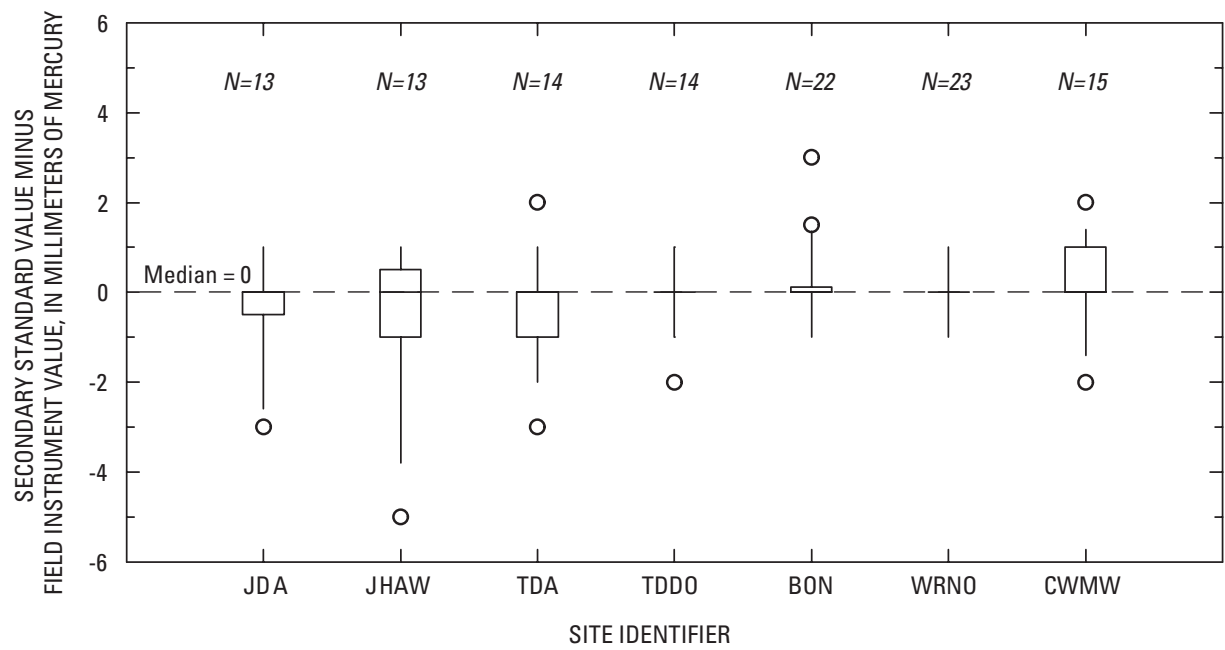

EXPLANATION

- Data values outside the 10th and 90th percentiles

90th percentile

75th percentile

25th percentile

10th percentile

$N=22 \quad$ Number of samples

Figure 3. Difference between the secondary standard and the field barometers. (Refer to table 1 for site identifiers.)

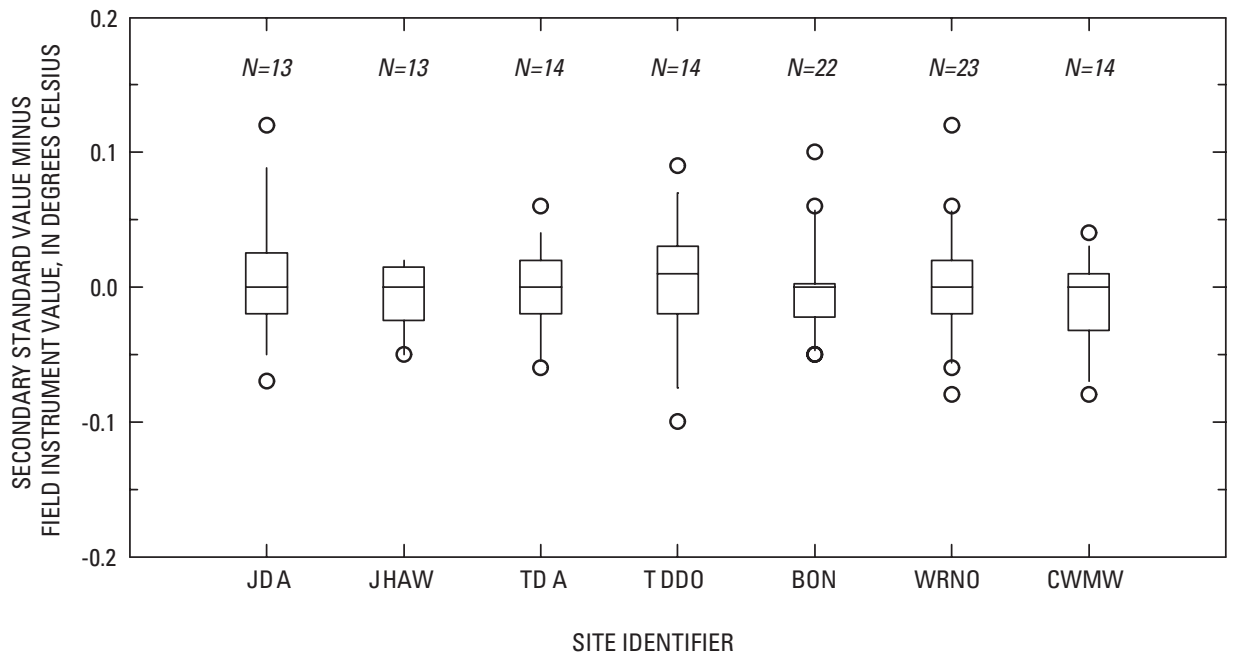

EXPLANATION

- Data values outside the 10 th and 90th percentiles

90th percentile

75th percentile

Median

25th percentile

10th percentile

$N=22 \quad$ Number of samples

Figure 4. Difference between the secondary standard and the field temperature instruments. (Refer to table 1 for site identifiers.)

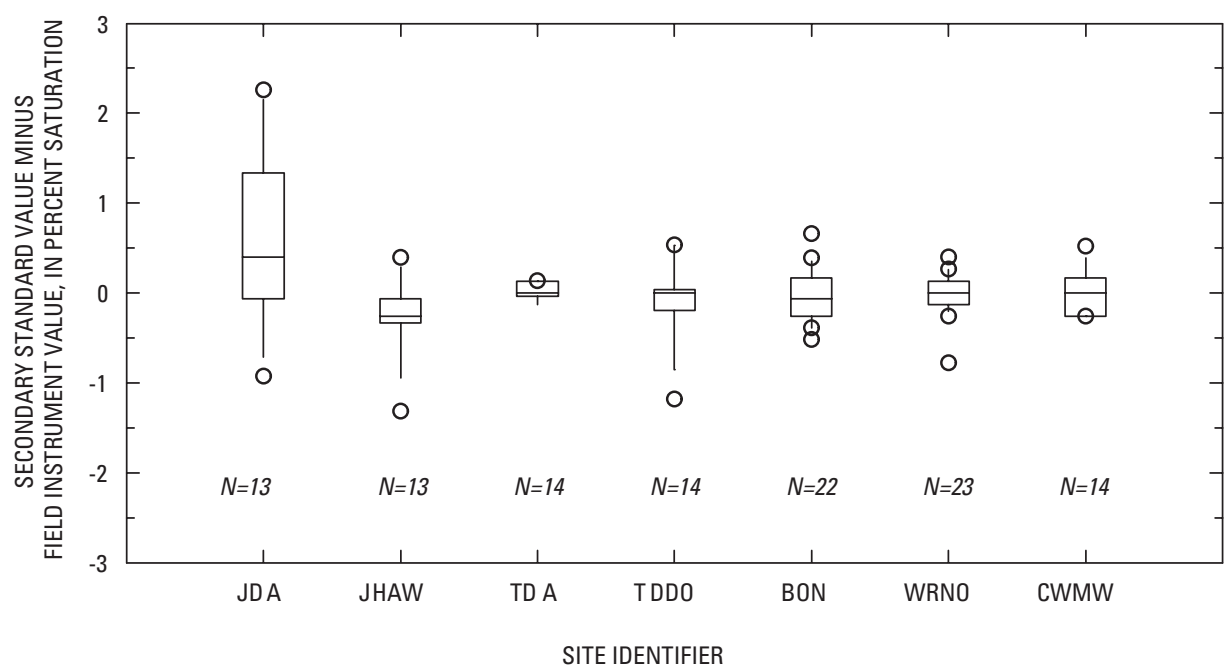

EXPLANATION

- Data values outside the 10th and 90th percentiles

90th percentile

75th percentile

Median

25th percentile

10th percentile

$N=22 \quad$ Number of samples

Figure 5. Difference between the secondary standard and the field total-dissolved-gas instruments. (Refer to table 1 for site identifiers.) 
Following deployment of the field TDG sensor for 2 to 3 weeks, the differences between the TDG sensor used as a secondary standard and the field TDG sensors were calculated after equilibration of the secondary standard unit to the site conditions. The side by side equilibrium was considered complete after a minimum of 20 minutes when the TDG values for each sensor remained constant for 4 to 5 minutes. As shown in figure 5, most of the data demonstrates less than $1 \%$ saturation difference between the two sensors. However, differences at the site at John Day forebay often exceeded this value. Two different TDG sensors were deployed at different times for field operation at the site. Both sensors yielded similar results, and both passed all calibration tests after deployment, suggesting that instrument malfunction was not the cause of the larger TDG differences. Although the secondary standard and field probes were positioned at approximately the same depth during the field checks, the field sensor was positioned inside a pipe housing and the secondary standard was positioned in open water. Partially stagnant water in the pipe may have caused the probe inside the housing (the field probe) to have smaller TDG measurements than the probe outside the housing (the secondary standard).

\section{EFFECTS OF SPILL ON TOTAL DISSOLVED GAS}

Spill from each dam increased the level of TDG downstream of the dam. Spill data are from the USACE (http://www.nwd-wc.usace.army.mil/ TMT/tdg_data/month.html). Spill from John Day Dam occurred from April 10 to August 31 (fig. 6). The spill was usually less than $160,000 \mathrm{ft}^{3} / \mathrm{s}$ (cubic feet per second) and often occurred only between 7:00 p.m. and 7:00 a.m. for fish passage considerations. Figure 6 shows that TDG downstream of John Day Dam increased in response to spill from the dam, with the TDG level usually being less than $120 \%$ saturation. During three time periods, June 4-9, June 28-July 2, and July 12, the spill from John Day Dam exceeded $160,000 \mathrm{ft}^{3} / \mathrm{s}$, causing the TDG at John Day tailwater to increase to values larger than $120 \%$ saturation.

Spill from The Dalles Dam (fig. 7) was continuous from April 10 to August 31 (except for several hours of no spill on June 26 and June 28). The spill generally was between 40,000 and $120,000 \mathrm{ft}^{3} / \mathrm{s}$, resulting in a TDG level of 110 to $120 \%$. During two time periods, June 2-9 and June 28-July 3, the spill from The Dalles Dam exceeded 140,000 $\mathrm{ft}^{3} / \mathrm{s}$, causing the TDG at The Dalles tailwater to increase to values larger than $120 \%$ saturation.
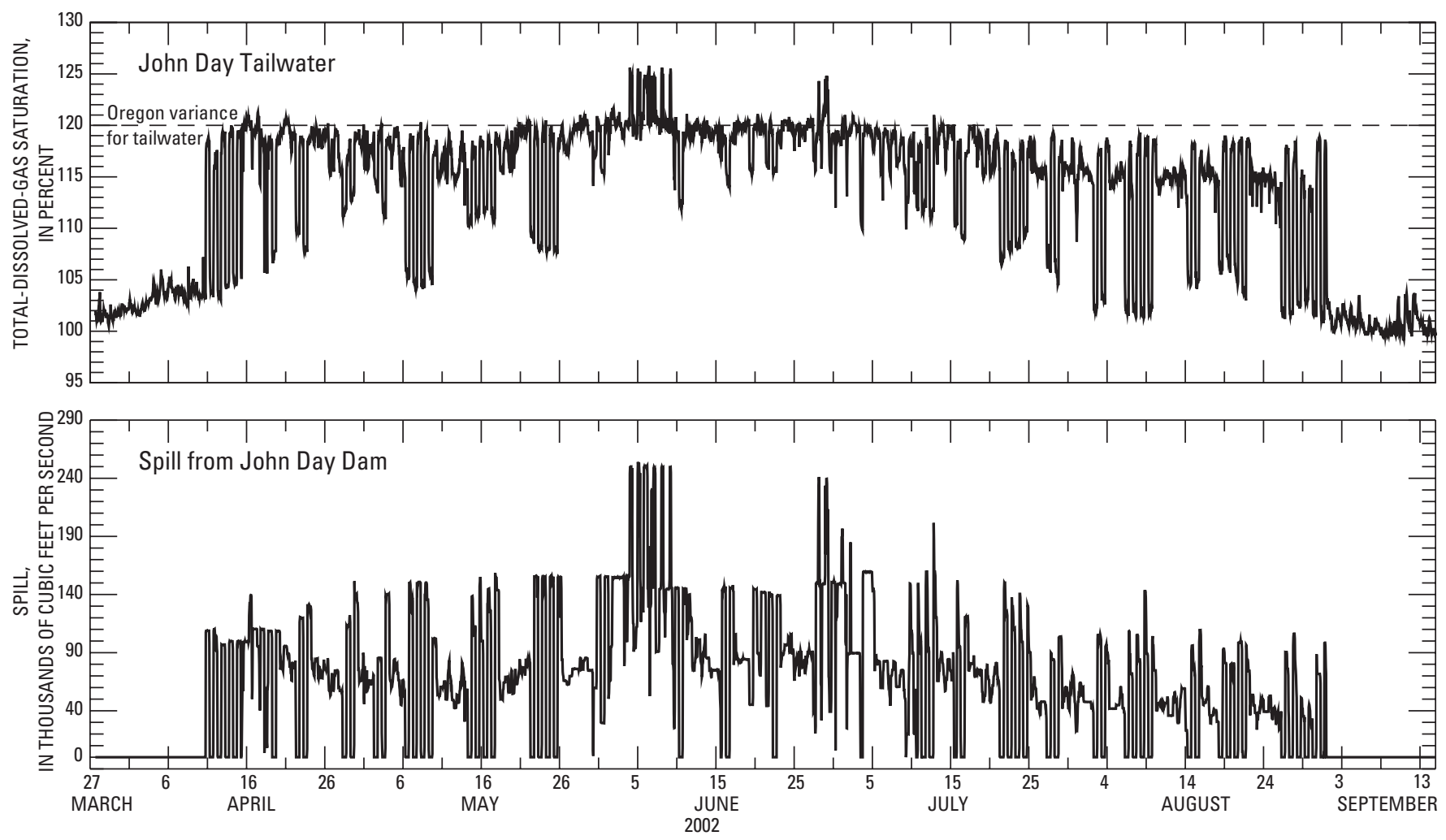

Figure 6. Total dissolved gas downstream of John Day Dam and spill from John Day Dam. 

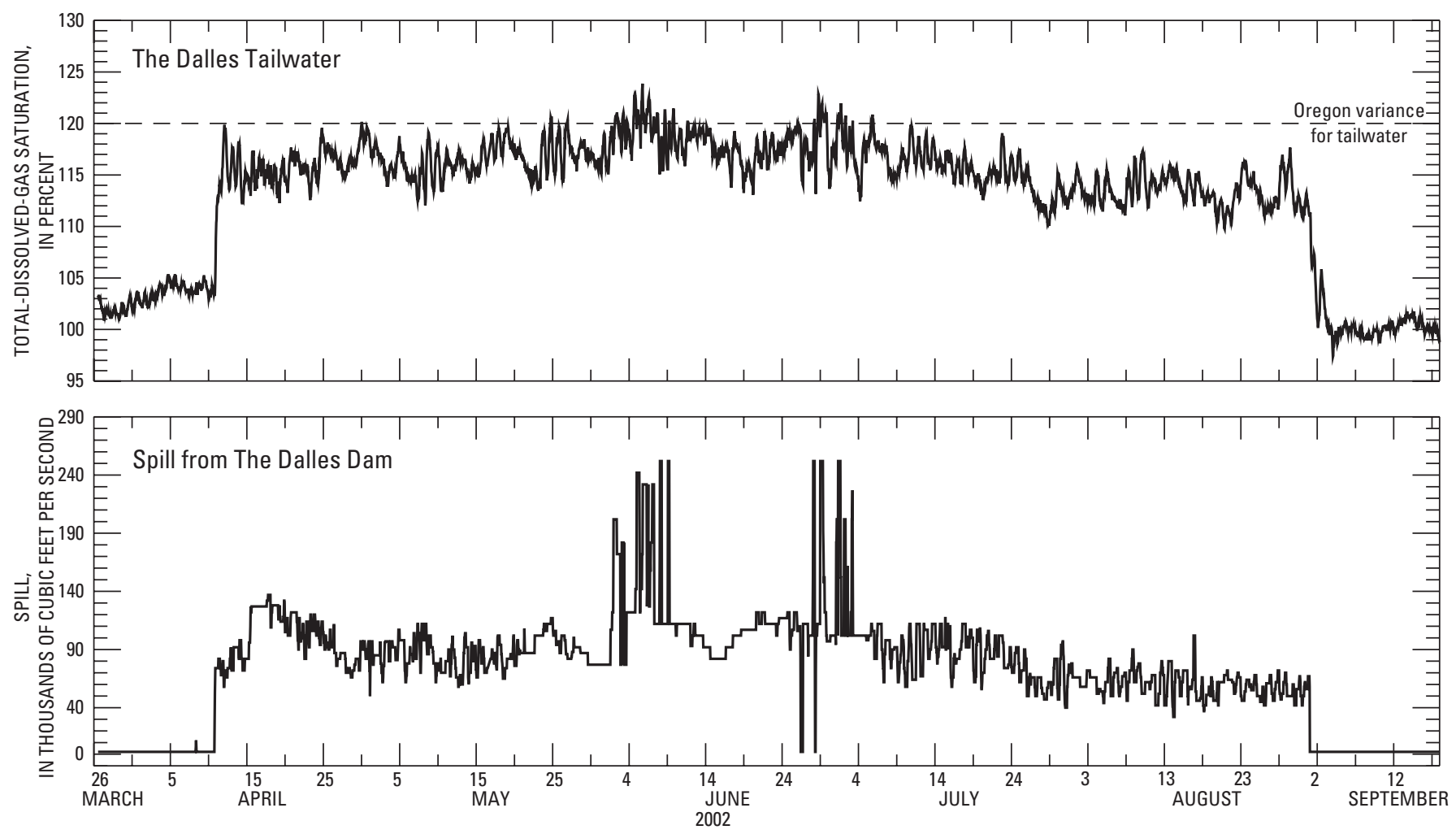

Figure 7. Total dissolved gas downstream of The Dalles Dam and spill from The Dalles Dam.

At Bonneville Dam, there were two periods of spill in WY 2002 (fig. 8). From March 12 to March 15, spill was as large as $100,000 \mathrm{ft}^{3} / \mathrm{s}$ to flush released hatchery fish to the ocean. During this spill the TDG at the Warrendale site (which is about 6 miles downstream of Bonneville Dam) increased to about $112 \%$. Periods of nearly continuous spill typically ranging from about 75,000 $\mathrm{ft}^{3} / \mathrm{s}$ to $150,000 \mathrm{ft}^{3} / \mathrm{s}$ from April 10 to August 31 caused TDG levels at Warrendale to rise to about $110-120 \%$ of saturation. During two time periods, June 1-11 and June 28-July 3, the spill from Bonneville Dam exceeded $170,000 \mathrm{ft}^{3} / \mathrm{s}$, causing the TDG at Warrendale to increase to values larger than $120 \%$ saturation.

\section{COMPARISON OF TOTAL DISSOLVED GAS AND TEMPERATURE TO STANDARDS}

In this report, compliance with only the Oregon water-quality standards for TDG and water temperature for the lower Columbia River are addressed. Washington standards, however, are similar to the Oregon standards. The State of Oregon water-quality standard for TDG is $110 \%$ saturation (Oregon Depart- ment of Environmental Quality, written commun., 2002). From April 1 to August 31, 2002, the USACE was granted a variance to this standard of $115 \%$ for forebay sites (John Day forebay, The Dalles forebay, Bonneville forebay, and Camas); and 120\% for tailwater sites directly downstream from dams (John Day tailwater, The Dalles tailwater, Warrendale, and Skamania). Although the Camas site is not located at the forebay of a dam, it is more than 24 miles downstream of Bonneville Dam and it is regulated as a forebay site. The variance was exceeded if the average of the highest 12 hourly values in one day (1:00 a.m. to midnight) was larger than the numerical standard.

At seven of the eight monitoring stations, the Oregon variance for TDG was exceeded at some time during WY 2002 (table 3). There were no exceedances at the Skamania site, which was operated only during March, before large amounts of spill occurred at Bonneville Dam. The site with the most exceedances was Camas, which exceeded the $115 \%$ variance 62 times, followed by Bonneville forebay, which exceeded the $115 \%$ variance 31 times. Overall, there were fewer exceedances at the tailwater sites, which had the larger variance of $120 \%$. 

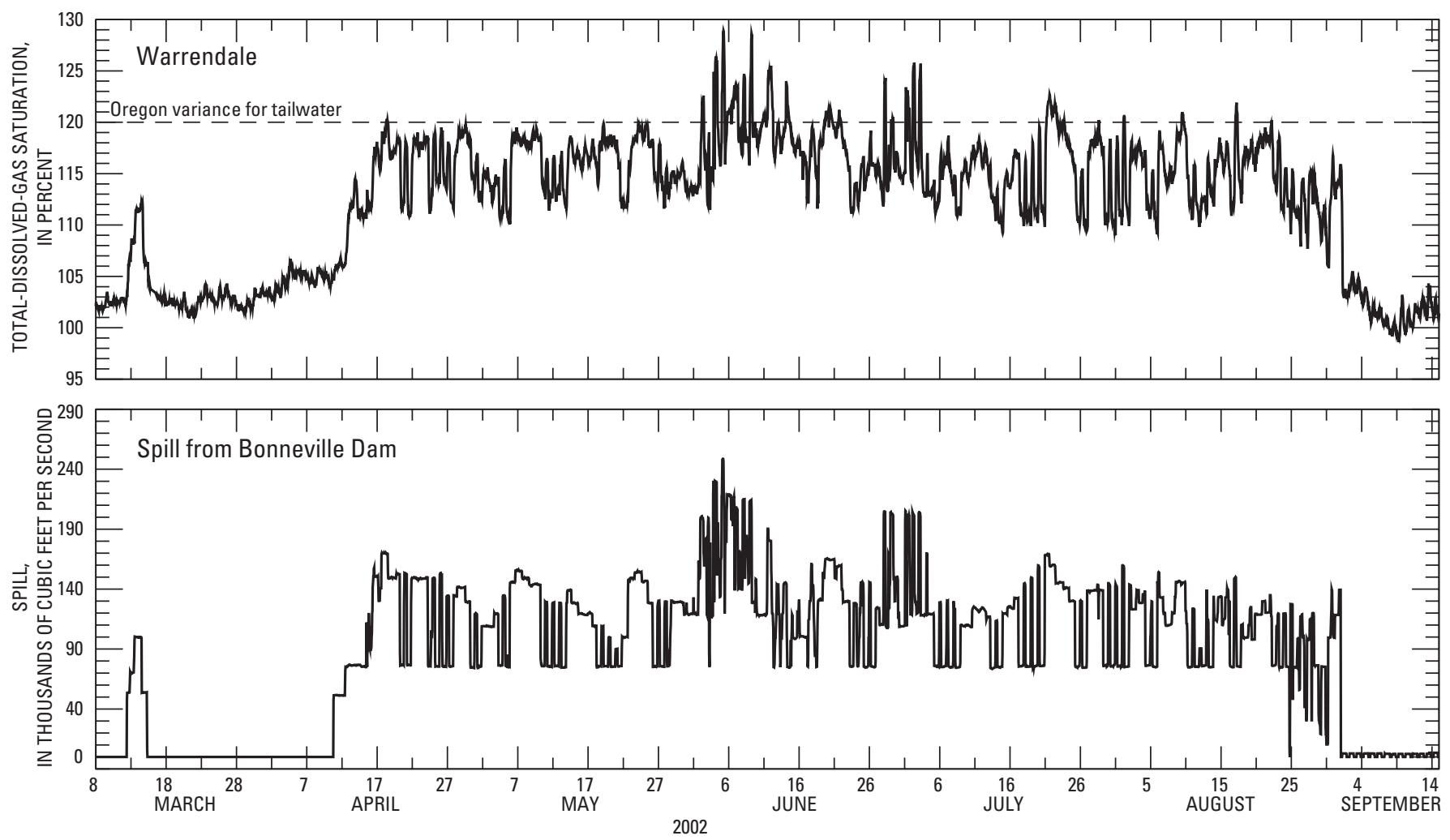

Figure 8. Total dissolved gas downstream of Bonneville Dam at Warrendale and spill from Bonneville Dam.

Table 3. Exceedances of State of Oregon Water-Quality variances for total dissolved gas, lower Columbia River, Oregon and Washington, water year 2002

[The variance was exceeded if the average of the highest 12 hourly values in one day (1:00 a.m. to midnight) was larger than the numerical standard (Oregon Department of Environmental Quality, written commun., 2002)]

\begin{tabular}{lcc}
\hline $\begin{array}{c}\text { Abbreviated } \\
\text { station name }\end{array}$ & $\begin{array}{c}\text { Numerical variance for } \\
\text { total dissolved gas, in } \\
\text { percent saturation }\end{array}$ & $\begin{array}{c}\text { Number of days } \\
\text { in exceedance } \\
\text { of variance }\end{array}$ \\
\hline John Day forebay & 115 & 11 \\
John Day tailwater & 120 & 25 \\
The Dalles forebay & 115 & 15 \\
The Dalles tailwater & 120 & 10 \\
Bonneville forebay & 115 & 31 \\
Skamania & 120 & 0 \\
Warrendale & 120 & 19 \\
Camas & 115 & 62 \\
\hline
\end{tabular}

Available data indicate that the forebay exceedances may have been the result of the cumulative effects of significant spill throughout the lower Columbia River. The TDG levels were often near $120 \%$ at the tailwater sites (figs. 6-8, and 9), and apparently the TDG often did not sufficiently degas to meet the $115 \%$ variance at the next downstream forebay sites.
There was an increase in both the median TDG level and the number of exceedances at the forebay sites moving downstream from John Day forebay to The Dalles forebay to Bonneville to Camas (fig. 9). Total maximum daily loads (TMDLs) for TDG are currently being discussed for the Columbia River (http://yosemite.epa.gov/r10/water.nsf/, accessed on October 30, 2002). If the TDG values in figure 9 were weighted for discharge, they would describe the TDG loads in the lower Columbia River. It was beyond the scope of this report to make these calculations, but they may be useful for evaluating the TMDLs in the future.

In WY 2002, the effects of spill on TDG outweighed the effects of temperature at Camas. In WY 2001, spills were generally small and infrequent, and increases in water temperature probably were responsible for some of the TDG exceedances at Camas (Tanner and Bragg, 2001, p. 12). Daily temperature increases above the daily average for late summer 2002 at Camas were about $0.5^{\circ} \mathrm{C}$ (fig. 10), and this would result in an increase of TDG by about $1.5 \%$ saturation, based on a computer program from Mike Schneider (USACE, written commun., 2002). 


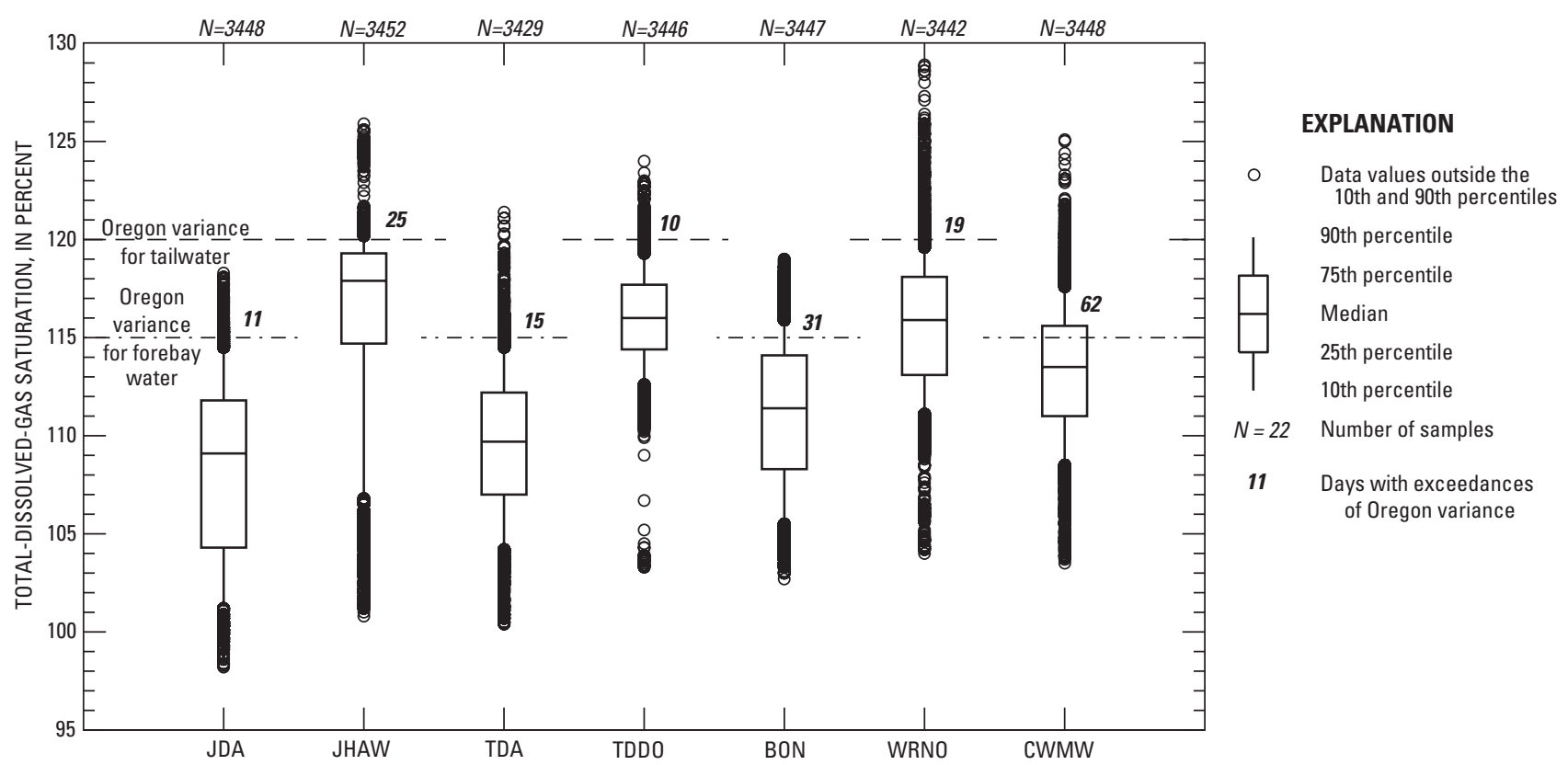

Figure 9. Total-dissolved-gas distributions and exceedances of Oregon Water-Quality variances, April 10, 2002 to August $31,2002$. (Refer to table 1 for site identifiers.)

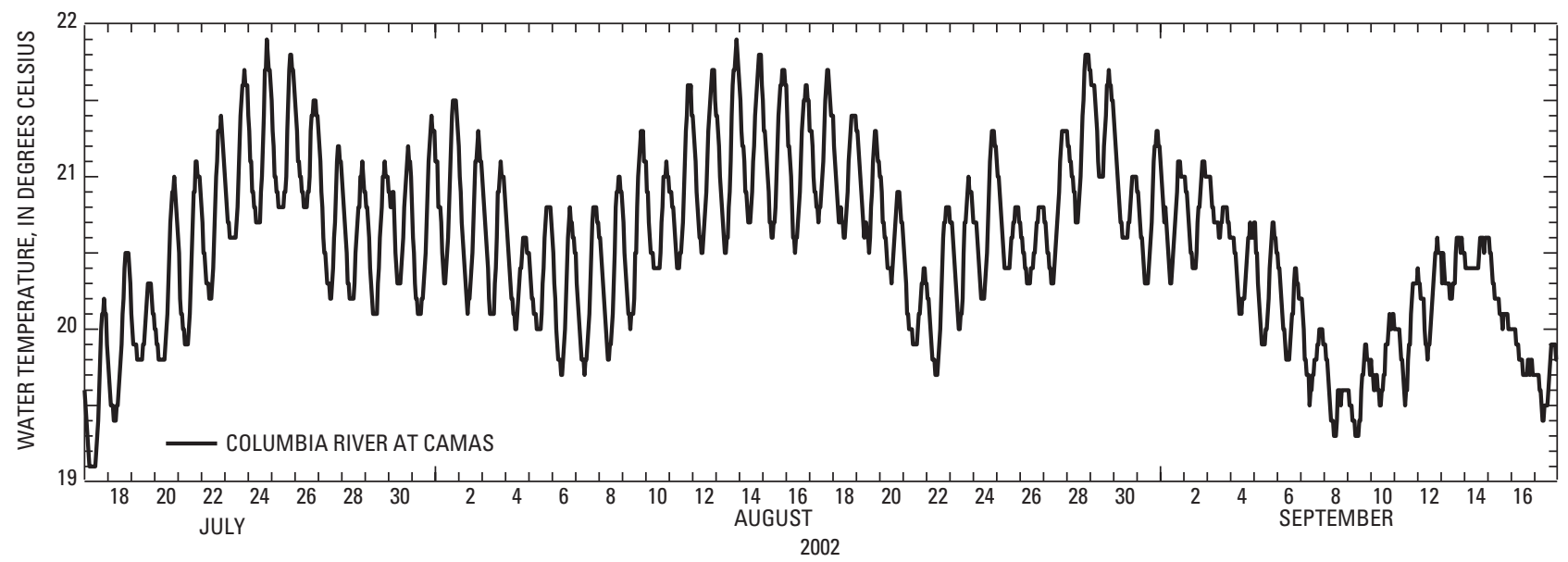

Figure 10. Water temperature at Camas for summer 2002.

The majority of the exceedances at Camas were by a larger margin than $1.5 \%$ saturation, illustrating the disproportionate control exerted by spill compared to water temperature in WY 2002.

Water-temperature standards that apply to the lower Columbia River are complex and depend on the effects of anthropogenic activities and the locations of salmonid rearing, spawning, and egg incubation areas. According to the State of Oregon water-quality standard, when the temperature of the Columbia River from RM 309 to the mouth exceeds $20^{\circ} \mathrm{C}$, no measurable surface-water temperature increase resulting from anthropogenic activities is allowed (Oregon Department of Environmental Quality website at http://www.deq.state.or.us/wq/wqrules/, accessed October 30, 2002). The Columbia River from RM 309 to the mouth includes all eight of the lower Columbia River TDG fixed stations. Water temperatures upstream and downstream of John Day Dam were equal to or higher than $20^{\circ} \mathrm{C}$ continuously from July 21 to September 17 (fig. 11). On several afternoons during this period, the water temperature at the forebay site transiently increased by up to about $2^{\circ} \mathrm{C}$ higher than the tailwater site. 


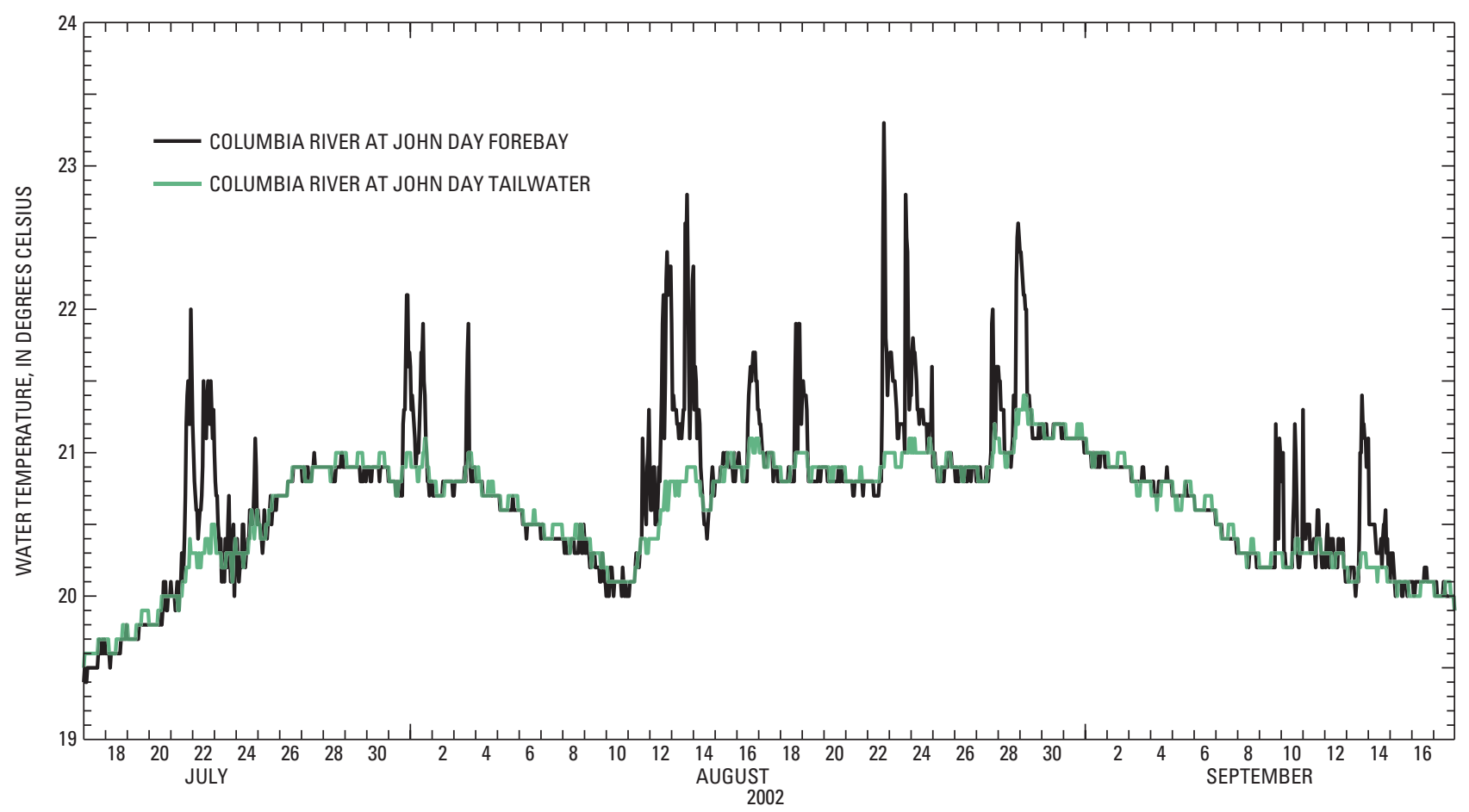

Figure 11. Water temperature upstream and downstream of John Day Dam for summer 2002.

This phenomenon has been described in the past (Tanner and Johnston, 2001, p. 19; and Tanner and Bragg, 2001, p. 11), and it has been attributed to localized heating of the stagnant surface layer of water near the monitoring station, which is on the upstream face of the dam.

Water temperatures upstream and downstream of The Dalles Dam were equal to or higher than $20^{\circ} \mathrm{C}$ continuously from July 20 to September 8 (fig. 12). The water temperature at The Dalles forebay was approximately equal to the temperature at The Dalles tailwater, indicating well-mixed conditions in the forebay, as contrasted to the John Day forebay.

Water temperatures upstream and downstream of Bonneville Dam were equal to or higher than $20^{\circ} \mathrm{C}$ almost continuously from July 21 to September 6 (fig. 13). The water temperature at Bonneville forebay was approximately equal to the temperature at Warrendale (the tailwater site) during the first part of the summer season, but after the spill and discharge at Bonneville Dam decreased beginning September 1, 2002, the Warrendale site had water temperatures that differed from those at the Bonneville site by up to about $1{ }^{\circ} \mathrm{C}$ (fig. 13).

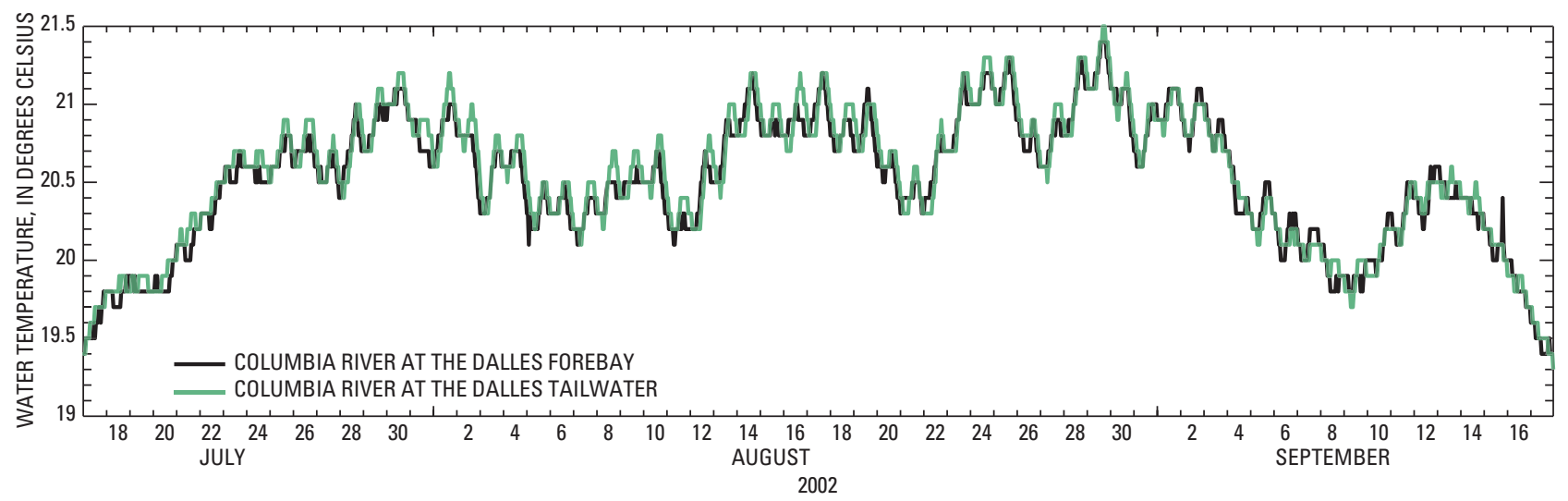

Figure 12. Water temperature upstream and downstream of The Dalles Dam for summer 2002. 


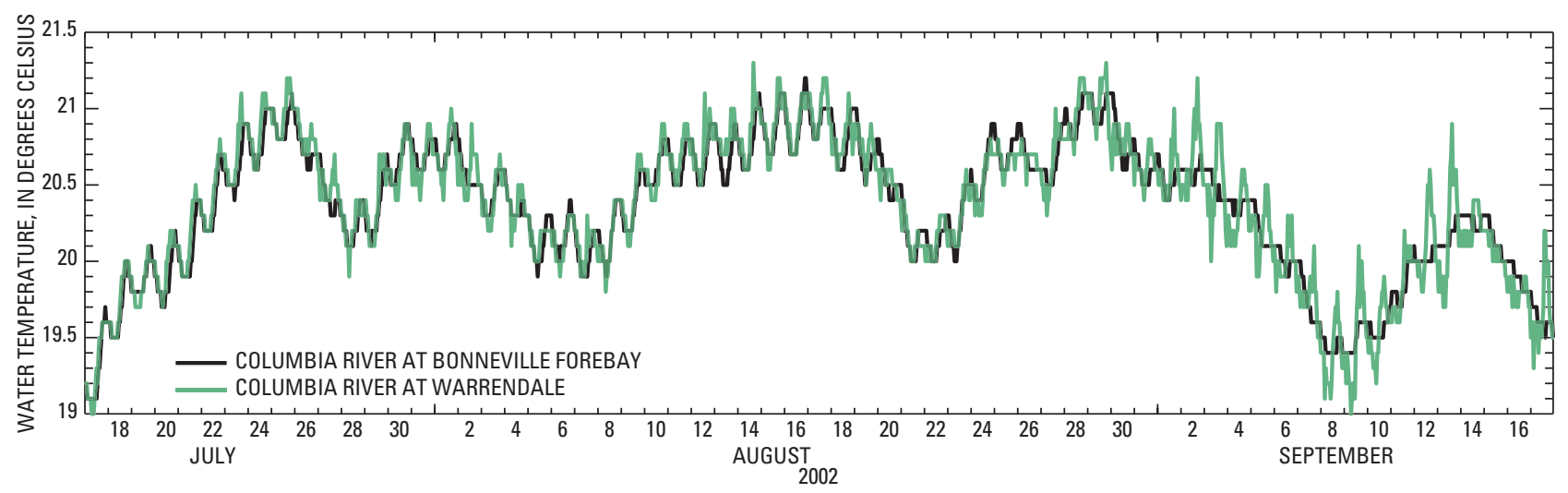

Figure 13. Water temperature upstream and downstream of Bonneville Dam for summer 2002.

At the Camas site, the water temperature was $20^{\circ} \mathrm{C}$ or higher for at least part of each day from July 16 to September 7 (fig. 10). During the summer, there was a distinct diurnal or daily cycle to the temperature, with an amplitude of about $1{ }^{\circ} \mathrm{C}$, a minimum at about 0900 hours, and a maximum at about 1900 hours. This is the same pattern found in 2001 (Tanner and Bragg, 2001, p. 11 and 12), and perhaps indicates the characteristics of the Columbia River where it is relatively unaffected by the dams. The effects of these temperature changes on TDG were discussed earlier in this section.

\section{REFERENCES CITED}

Colt, J., 1984, Computation of dissolved gas concentrations in water as functions of temperature, salinity, and pressure: American Fisheries Society Special Publication $14,154 \mathrm{p}$.

Jones, J.C., Tracey, D.C., and Sorensen, F.W., eds., 1991, Operating manual for the U.S. Geological Survey's data-collection system with the geostationary operational environmental satellite: U.S. Geological Survey Open-File Report 91-99, 237 p.

Tanner, D.Q., and Bragg, H.M., 2001, Quality-assurance data, comparison to water-quality standards, and site considerations for total dissolved gas and water temperature, lower Columbia River, Oregon and Washington, 2001: U.S. Geological Survey WaterResources Investigations Report 01-4273, 14 p.

Tanner, D.Q., Harrison, H.E., and McKenzie, S.W., 1996, Total dissolved gas, barometric pressure, and water temperature data, lower Columbia River, Oregon and Washington, 1996: U.S. Geological Survey Open-File Report 96-662A, 85 p.

Tanner, D.Q., and Johnston, M.W., 2001, Data-collection methods, quality-assurance data, and site considerations for total dissolved gas monitoring, lower Columbia River, Oregon and Washington, 2000: U.S. Geological Survey Water-Resources Investigations Report 01-4005, 19 p.

U.S. Environmental Protection Agency, 1986, Quality criteria for water: Washington, D.C., EPA-440-5-86-001. 